\title{
A Geographic Information System Based Soil Erosion Assessment for Conservation Planning at West Hararghe, Eastern Ethiopia
}

\author{
Hailu Mosisa Chala ${ }^{1} \quad$ Biru Jiru Dadi ${ }^{2}$ \\ 1.Water Resources \& Irrigation Engineering Dep't, IOT, Oda Bultum University; p.o box: 226, Chiro, Ethiopia \\ 2.Hydraulics \& Water Resources Engineering Dep't, IOT, Oda Bultum University; p.o box: 226, Chiro, Ethiopia
}

\begin{abstract}
Soil erosion by water is a serious concern worldwide problem and it is difficult to assess its economic and environmental impacts accurately. West Hararghe zone is one of the most erosion-prone areas in the eastern highland of Ethiopia which little attention is given. The objectives of this study were to estimate the magnitude of soil loss rate, assess the change of erosion risk, and elucidate their implication for SWC planning in West Hararghe Zone, Eastern Ethiopia. Applying remote sensing data, the study first derived the Revised Universal Soil Loss Equation (RUSLE) model parameters in an ArcGIS 10.3 environment and estimated the soil loss rates. This model was developed based on the integrated use of precipitation data, Landsat images in 2017, and 2018, terrain parameters (slope gradient/steepness and slope length), soil loss management practice and soil composition in west Harerge Zone, Oromia Regional state, Ethiopia. The estimated total soil loss in the Zone was 47,288,835.17 tons in 2017/18 with a mean erosion rate of $28.62 \mathrm{t} \mathrm{ha}^{-1} \mathrm{yr}^{-1}$. The study area was divided into six erosion risk classes ranging from low to high. About 27.70\% (457,687.19 ha) of zone was classified under high to very high soil loss class while the remaining $72.30 \%(1,194,613.1314$ ha) of the zone categorized under slow to moderate soil loss class.
\end{abstract}

Keywords: - GIS, RUSLE, Soil loss potential, West Harerge Zone, Ethiopia

DOI: $10.7176 / \mathrm{CER} / 11-2-02$

Publication date:March $31^{\text {st }} 2019$

\section{INTRODUCTION}

Soil erosion is a phenomenon present in all regions of the world. It is a threat both to human beings and the natural environment. The need to mitigate the negative effects of erosion has become urgent in the beginning of the 20 century. Since then, scientists have been developing models to help understand the factors that influence erosion and the processes related to it. Some of these models were purely empirical - relying on statistical relationships between the values measured in field and the soil sediment yield. Other tried to describe the physical processes by means of mathematical equations like mass conservation laws or laws describing movement of water (Betelhem, 2018).

Erosion is an inclusive term for the detachment and transport of soil by the action of erosive agents: water and wind, and influenced by factors such as climate, soil, vegetation, and topography (Niu et al., 2003; Demirci and Karaburun 2012). Most concerns about erosion are related to accelerated erosion, where the soil loss rate has been significantly increased by human activities such as changes in land cover and management (Gobin et al., 2002).

For developing nations, soil erosion is among the most chronic environmental and economic burden (Taffa, 2002). In Ethiopia agriculture forms the dominant sector of the economy which provides about $52 \%$ of the country's gross domestic product (GDP), over $80 \%$ of its employment, and $90 \%$ of its export earnings (World Bank, 2000). The rates of soil erosion in Ethiopia are frighteningly high. Serious erosion is estimated to have affected $25 \%$ of the highland area. Close to $4 \%$ of the highlands are now so seriously eroded that they will not be economically productive again in the foreseeable future (Teklu and Gezahegn, 2003) (Atnafe et al., 2015).

Soil erosion especially water erosion on cropland is one of the most severe problems affecting the agricultural sector in Ethiopia (Sonneveld 2002). An alarming message indicated that (FAO 1998a; Sonneveld 2002), Ethiopia could lose nearly all its top soil within 100-150 years which will have significant negative impacts on the ecological balance and the livelihood of the society. Study conducted by Devi et al. (2008) in the Gilgel Gibe catchment at one of the tributary of the Gilgel Gibe I dam, taking the contribution of sheet erosion alone found the annual sediment load to be about $4.50 \times 107$ tons (Lencha et al., 2015).

Ethiopia suffers from food insecurity with average annual food production growth an estimated $2.4 \%$, lagging behind population growth of $2.8 \%$ per annum. Major causes of food insecurity in Ethiopia include environmental degradation, deforestation, soil erosion, recurrent droughts and pressures caused by population growth. Across the country, environmental degradation has led to loss of production capacity, leaving crop cultivation and livestock husbandry struggling to withstand the immediate impacts of climate variability, including recent El-Nino events and associated floods and droughts (Betelhem, 2018).

Ethiopian agriculture is one of the most vulnerable sectors to current climatic variability and projected climate change, potentially exposing millions of people to recurrent food shortages and episodic famines. 
Negative impact of climate change and variability on crop and livestock production could result in a nationwide food shortage and greatly hinder the economy (Assefa et al., 2008). For instance, droughts in Ethiopia can shrink household farm production by up to $90 \%$ of normal years output and could lead to the death of livestock and human beings (World Bank, 2003). As cited by (Betelhem, 2018)

Long term trends towards reduced rainfall and recurring droughts have played a role in weakening of the Ethiopian economy (USAID, 2004) and it continues to be a major challenge for the Ethiopian community (United Nation, 2008). In the twenty-first century there has been a rising frequency of extreme droughts due to global warming in Ethiopia IDS, 2008. The country has faced sharp droughts at least twice per decade. For the last five to seven decades, with the most serious ones in 1972-73, 1984 and 2002-03 (Mideksa, 2010).

Ethiopia is affected by different environmental challenges, and water-induced soil erosion is one of the keys to finding sustainability to agricultural production and productivity to safeguard food security (Araya et al., 2012); FDRE, 2011. Agriculture is the backbone of the country's economy and sustains the livelihood of about $85 \%$ of the population; loss of productive soil by erosion has massive environmental and economic impacts UK, 1999; (Ayalew, 2015). Reports from the Food and Agriculture Organization (FAO, 1986) estimated the annual soil loss in Ethiopia is about 1.5 billion tons. According to the study by the FAO 1986, about 27 million hectares of the land, nearly half of the Ethiopian highland areas, were affected by serious soil erosion. Particularly, in Wollo, Tigray, and Hararghe, half of the agricultural land has soils with a depth of less than $10 \mathrm{~cm}$ (Gebreyesus, 2014). This problem has decreased the soil production potential. For example, the annual productivity potential of land in the Ethiopian highlands is declining by $2.2 \%$ per year (Gebreyesus, 2014).

In response to rapid population growth and accelerated threats of water-induced soil erosion risk, the Ethiopian government has taken SWC measures (MoFED, 2010 and MFEDEPPD, 2003). Since it is difficult to address conservation problems at the time, it is important to identify areas that are highly vulnerable to soil erosion for conservation measures (Hurni, 1988, Baraket et al., 2014). Given the shortcomings in the traditional soil erosion risk assessment methods, one needs a more systematic approach to do an effective soil erosion assessment (Baraket et al., 2014). Significant efforts have been made at local and global levels to assess the magnitude of soil erosion risk. This has certainly made a promising ground for sustainable use planning and an appropriate SWC strategy development at the watershed or basin scales (Claessens et al., 2008).

Many models have been developed and applied for the prediction soil erosion. The major models include Modified Universal Soil Loss Equation (MUSLE), the Universal Soil Loss Equation (USLE), Morgan-MorganFinney (MMF), Agricultural Non Point Source Model (AGNPS), Erosion Productivity Impact Calculator (EPIC), Water Erosion Prediction Project (WEPP), Soil and Water Assessment Tool (SWAT), and European Soil Erosion Model (EUROSEM) (Williams, 1975); (Morgan 1998). Among these models, the RUSLE is the most widely applied empirical model for offering quantitative soil erosion estimation and conservation planning around the globe (Adediji, 2010); (Panagos, 2015); (Chang, 2014).

RUSLE, model in combination with satellite remote sensing and Geographic Information Systems (GIS) mapping techniques, was found to be a convenient tool for soil loss assessment and successful conservation planning (Panagos, 2015). There have been many prediction model-based studies conducted in various parts of Ethiopia for soil erosion risk assessment and conservation planning by integrating them with remote sensing data and GIS technology over the past few years.

In Oromia Regional state soil erosion is the most widespread form of land degradation in the region and most research on understanding the degradation process and finding a solution to combat it has concentrated on this topic. The average erosion rate for agricultural land has been estimated at about $40 \mathrm{t} / \mathrm{ha}$ but there is wide variation between different parts of the region and between production systems. Several factors contributing to erosion include (Bezuayehu et al., 2002).

West Hararghe zone, where soil loss information and evaluation of risk of potential soil erosion was very few and not assisted with GIS technique were preferred for this study. Thus, an attempt were made to estimate and map the spatial pattern of annual soil loss rate by water using Revised Universal Soil Loss Equation (RUSLE) simulated by GIS 10.3. This research had answered to four core research questions; how much of soil is lost per unit area of land annually in each Woreda of the zone? How is the spatial distribution of soil loss rate in the zone? Does the estimated soil loss rate exceed the tolerable limit of soil erosion set by FAO? And where is erosion hotspot areas located for conservation prioritization? So as general objective this study was estimate the rate of soil erosion and soil loss potential of western Hararghe zone, eastern Ethiopia.

Therefore, this study was designed

a) To classify the area according to their soil loss risk;

b) To estimate the sediment yield of the study area;

c) To identify where is erosion hotspot areas located for conservation prioritization in West Hararghe Zone; Eastern Ethiopia 


\section{MATERIALS AND METHODS}

\subsection{Description of the Study Area}

\subsubsection{Location}

West Hararghe is one of the Zones in Oromia Regional state of eastern Ethiopia. West Hararghe has a coverage area of 16,523.0032 square kilometers, which bordered on the south by the Shebelle River which separates it from Bale, on the southwest by Arsi zone, on the northwest by the Afar Region, on the north by the Ethiopia Somali Region and on the east by East Hararghe zone. The zone is found at 7050' 00" to 9030' 00" N latitude and 40010'00" to 41045'00" E longitude.

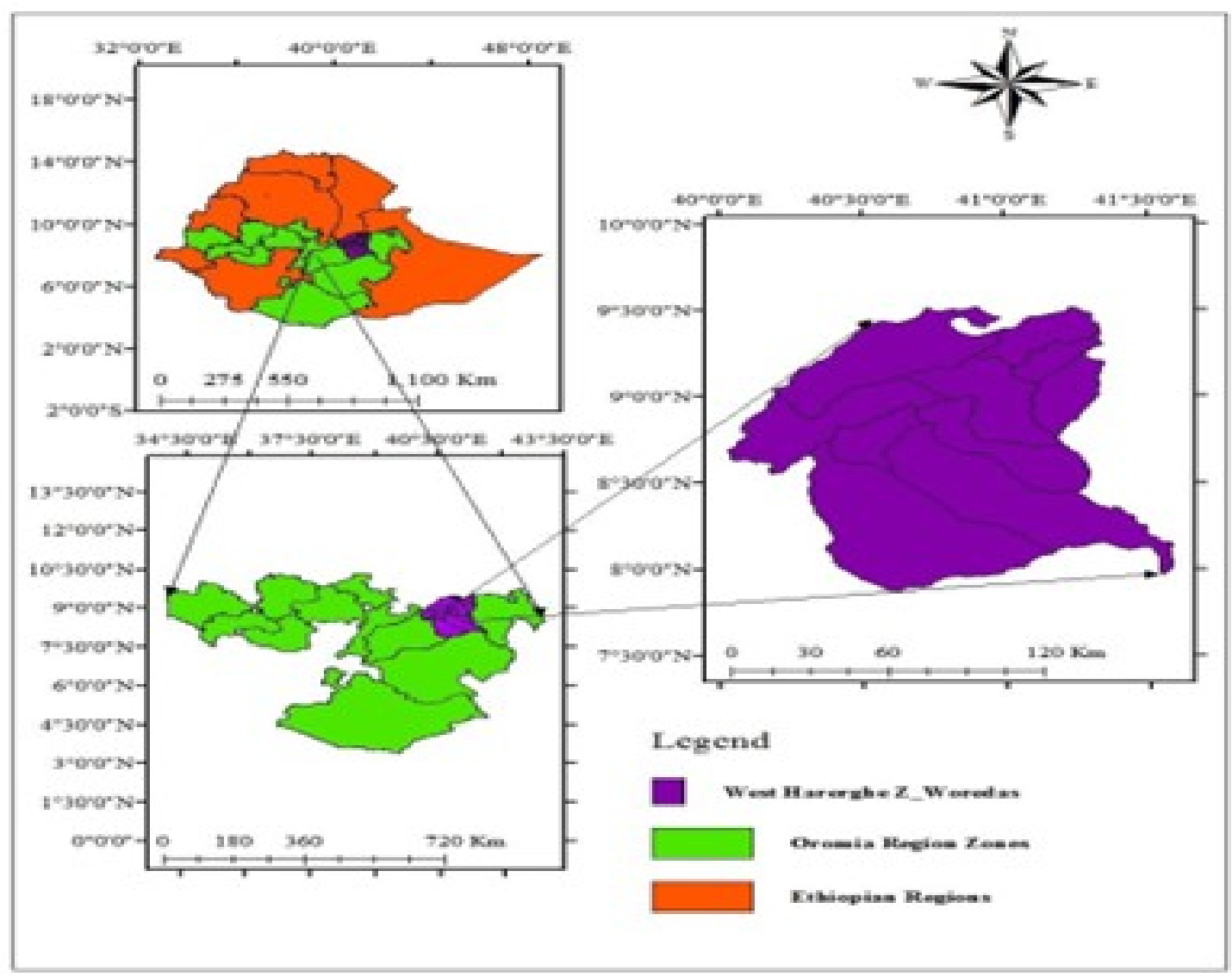

Figure 1. Map of study area (West Hararghe Zone topo map)

\subsubsection{Climate}

Daily, monthly, and annual rainfall and temperature data collected from Ethiopian Meteorological Agency through satellite (global weather data for SWAT input) for the years from 1998 to 2017 show this information. The mean annual rainfall of the area is estimated as $1290.34 \mathrm{~mm}$. with Maximum monthly rain fall of $600 \mathrm{~mm}$ at august month and minimum monthly rain fall of $0 \mathrm{~mm}$ at January \& February months on the area. More than $90 \%$ of the rain occurs from June to September; July and August being the wettest months. The average maximum and minimum daily temperatures vary from $30.60 \mathrm{C}$ and $4.440 \mathrm{C}$ respectively.

\subsubsection{Topography}

The study area is a mountainous and highly trained with gentle and steep slopes. The elevation of the study area ranges from $1733-3,574 \mathrm{~m}$ above mean sea level. Most of the land in the area is characterized with mountainous, with which most of the area have an average elevation of 2271.00 m.a.s.1. The highest point in this Zone is Mount Arba Gugu3,574 m a.m.s.l. 


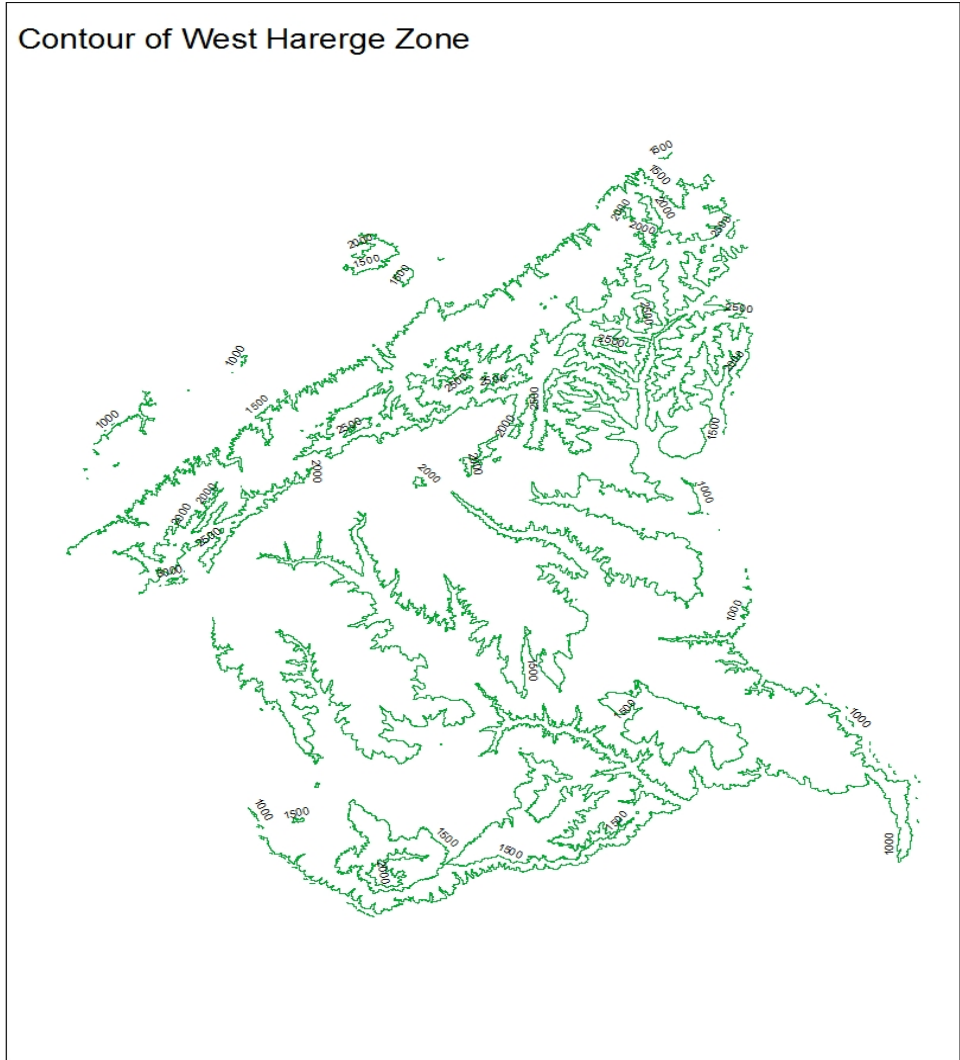

Figure 2. topography of study area

\subsection{Materials and Chemicals}

In order to undertake this research, the following materials and chemicals were used either in the field or in the laboratory, like.

\# PC based software models (RUSLE Model):- to estimate the soil loss of the study area.

* Computer based GIS package Software (ArcGIS 10.3, Arc hydro tools 10.3, ERDAS Image 10):- to delineate the topo map of study area, to run RUSLE model and generate the RUSLE model parameters, to run ERDAS software.

\# Surveying instruments (measuring tape, GPS, level and rod, marker, pegs):- for the purpose of sample area delineation, coordination identification of sample area, land use land cover and conservation practice identification.

* Soil Sampling material (auger, polyethylene (plastic) bags, core sampler, hammer, knife, GPS, flat wood, meter.):-this materials used to take soil sample, to identify the place where the sample taken and prepare the sample for laboratory test.

* Laboratory material (Grading materials; Hammer), Sieve, Electronics balance, Prex glass, Magnetic stirrer, Reciprocating shaker, Borosilicate glass, Mixing metal, oven dry plate, Distil water):- used to test the soil texture, organic matter and permeability.

The following chemicals were used in laboratory during the study.

$\checkmark \quad$ sodium carbonate $(\mathrm{Na} 2 \mathrm{Co} 3)$

$\checkmark \quad$ sodium heza Meta phosphate $(\mathrm{NaPo} 3)$

$\checkmark$ potassium dichromate solution

$\checkmark$ concentrated sulfuric acid

$\checkmark$ concentrated orthophosphoric acid

$\checkmark$ ferrous sulfate solution

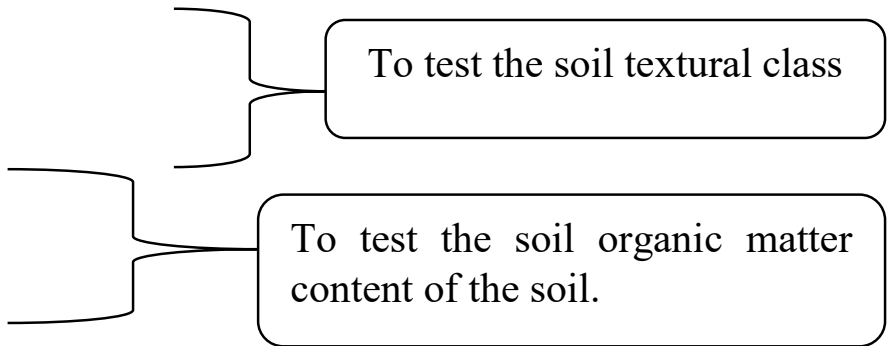

\subsection{Data collected}

Primary data (soil and water conservation structure information, soil texture, and soil particle size by soil sampling) were collected. Field observations were carried out to collect ground control points (GCP) for image 
classification and soil loss vulnerability verification.

Secondary data such as monthly climatic data for 20 years (1998 to 2017) from national metrological agency (NMA), Satellite image (Landsat8, 2017) (LDCM), topographic map (west Hararghe Zone Water Resources, Energy and Irrigation Agency Bureau), soil data created by MoWIE Oromia Regional digital Soil map at 1:150,000 scale from Ministry of Water, Irrigation and Energy (MoWIE in 2017) were collected.

\subsubsection{Estimation of missed rainfall data}

Estimation of missed data values of station is often desirable to use the data. In this study, the data for base station or west Harerghe metrological station missed data were estimated. XLSTAT tools (nearest neighbor estimation method) used to complete missed data. Most XLSTAT functions include options to handle missing data. However, only few approaches are available. This tool allows completing or cleaning dataset using advanced missing value treatment methods using the nearest neighbor station (Allison, 2001).

\subsubsection{Consistency and homogeneity of meteorological data}

The data consistency of the given metrological stations was cheeked with the help of double mass-curve method with in reference to their neighborhood stations. The double mass curve was plotted by using the annual cumulative total rainfall of the base station (stations in west Hararghe zone) as ordinate and the average annual cumulative total of neighboring stations as abscissa. The homogeneity of annual rainfall of study area station was tested using XLSTAT 2016 software SNHT test (Alexanderson, 1986). The SNHT test (Standard Normal Homogeneity Test) was developed by Alexanderson (1986) to detect a change in a series of rainfall data. The test is applied to a series of ratios that compare the observations of a measuring station with the average of several stations. The ratios are then standardized. The series of $\mathrm{X}_{\mathrm{i}}$ corresponds here to the standardized ratios. The null and alternative hypotheses are determined by:

$\mathrm{H}_{0}$ :- The $\mathrm{T}$ variables $\mathrm{X}_{\mathrm{i}}$ follow a $\mathrm{N}(0,1)$ distribution.

$\mathrm{H}_{\mathrm{a}}$ : - Between times 1 and $v$ the variables follow an $\mathrm{N}\left(\mu_{1}, 1\right)$ distribution, and between $v+1$ and $\mathrm{T}$ they follow an $\mathrm{N}\left(\mu_{2}, 1\right)$ distribution.

$$
\mathrm{T}_{\mathrm{O}=\max } \quad 1<z<T\left(v Z_{1}^{2}+(n-v) z_{2}^{2}\right)
$$

With

$$
\begin{aligned}
& z_{1}=\frac{1}{v} \sum_{t=1}^{D} x_{t} \\
& z_{2}=\frac{1}{n-v} \sum_{t=v+1}^{T} x_{i}
\end{aligned}
$$

The To statistic derives from a calculation comparing the likelihood of the two alternative models. The model corresponding to $\mathrm{H}_{\mathrm{a}}$ implies that $\grave{1}_{1}$ and $\grave{i}_{2}$ are estimated while determining the $\mathrm{n}$ parameter maximizing the likelihood. XLSTAT evaluates the p-value and an interval around the p-value by using a Monte Carlo method.

$\mathrm{T}=$ is successive times

\subsubsection{Digital Elevation Model}

DEM (Digital Elevation Model) represents the spatial distribution of elevation of the surface in digital format. DEM has become vital input for automated generation of terrain and hydrologic features. It is the source for generation of terrain features like slope, aspect, hill shade, and other relief features. It has also some hydrologic application for the zone, such as determining flow direction and flow accumulation.

DEM is also vital input for soil erosion modeling. For the study, the modified LS-factor map was generated from the slope and flow accumulation map derived from the DEM. To create DEM of the study area contour map was digitized from the topographic maps of 1:60,000 scale with contour interval of $30 \mathrm{~m}$.

\subsection{Data Analysis techniques}

Data analysis with GIS includes generation of zonal topomap; generation of R, K, LS, C and P and reclassification of derived datasets. Digital image processing, preprocessing of satellite image data, masking the image with the zonal boundary; earth resources data analysis system (ERDAS 10) software was used for land use land cover class. Data analysis and processing were made by digitizing, calculating and classifying the necessary information of each layer with the help of ArcGIS 10.4 software and RUSLE model. Furthermore, some simple statistical methods, such as percentage, average and graphic tabulation were also employed for the analysis and interpretations as it has shown under below sections.

\subsubsection{RUSLE Model}

The study area was extracted from the shape file that indicates administrative zone and re-projected to UTM projection $37 \mathrm{~N}$. Then it was used to clip all digital data and all data sets then were defined and re-projected to the same projection.

The basic methodological approach followed in RUSLE has been detailed in the following simplified flow chart in which all the variables combine together to develop the RUSLE model (Figure 3). 


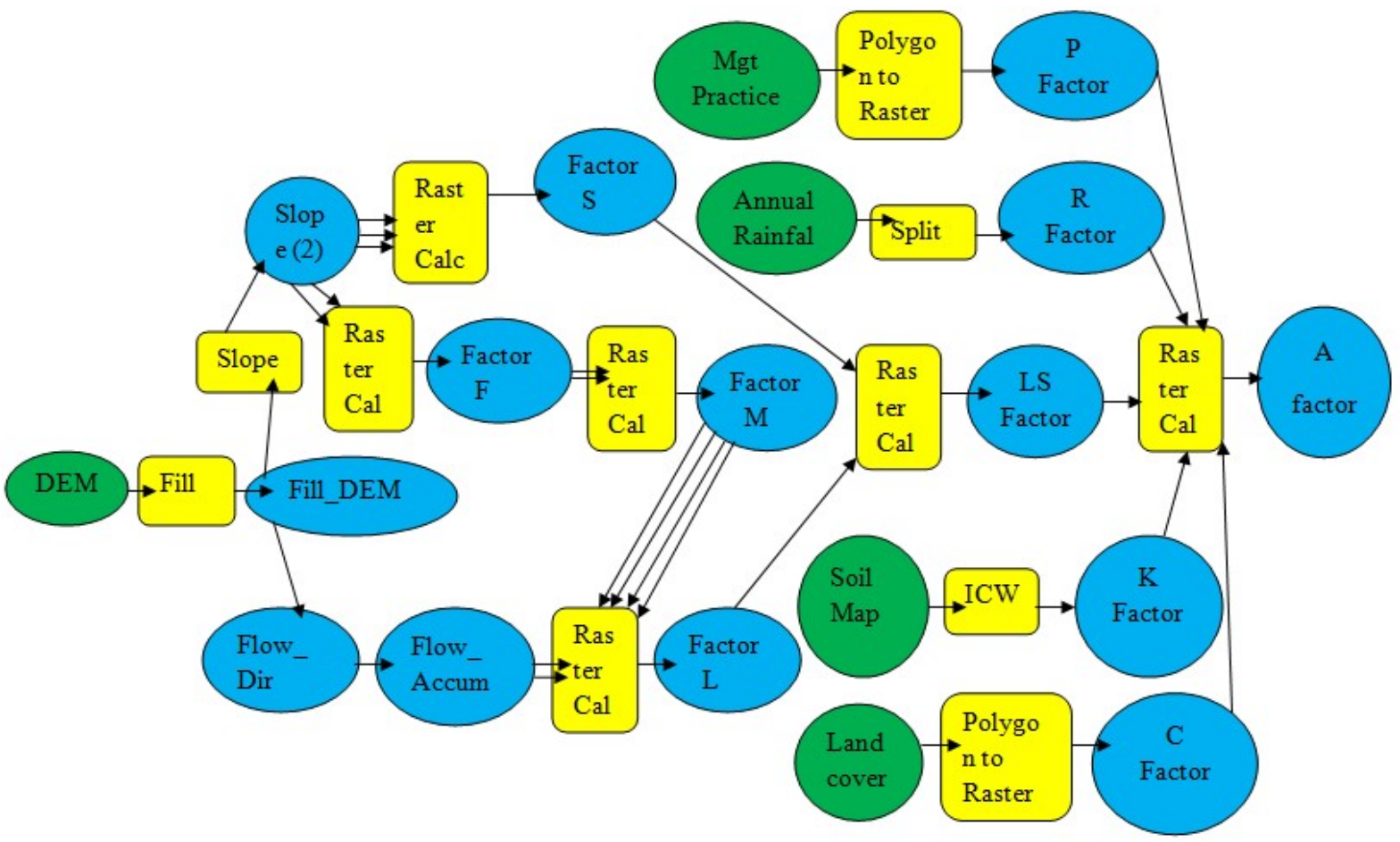

Figure 3. Simplified flow chart of RUSLE Model

\subsubsection{R-Factor (rainfall erosive)}

The erosive factor $\mathrm{R}$ was calculated according to the equation given by Hurni (1985), derived from a spatial regression analysis (Hellden, 1987) for Ethiopian conditions based on the available mean annual rainfall (p) (Equation 3.2).

$$
\mathrm{R}=-8.12+0.562 * \mathrm{P}
$$

Where

$\mathrm{R}$ Rainfall erosive, $\mathrm{P}$ the mean annual rainfall in $\mathrm{mm}$

The monthly rainfall, for the study area was collected from twelve metrological stations (Chiro, Mechara, Hirna, Gelamso, Badessa, Kuni, Meiso, Eerer, Arbabordede, Tedecha belia, Mekela, Asebot) from National Meteorological Service Agency (NMSA, 2017). Monthly rainfall records of the stations for 20 years from 1998 to 2017 were used to calculate the rainfall erosive factor (R-value). The mean annual rainfall was first interpolated to generate continuous rainfall data from each station by "3D Analyst Tools Raster Kriging Interpolation" in ArcGIS 10.3 environment after necessary missed data were estimated to obtain spatial continuous data of R-value.

\subsubsection{K-Factor (soil erodibility factor)}

A soil map from FAO et al., (1998b) and FAO et al., (2009) were used and, soil erodibility factor was determined using relationships as suggested by Neitsch et al. (2002). The principal factor affecting K_value are texture, structure, organic matter and permeability are also important contributors (Robert and Hilborn, 2000). The soil data was collected from MoWIE of Oromia Regional state digital Soil map and Spatial Analyst Tool in GIS environment was used to obtain soil units map of the study area. Depending on digitalized developed soil map, sixty soil samples using auger were collected from different locations representing soil type to analyze texture, organic matter, permeability, at soil laboratory and structure at field identification, and the K factor were identified by regression equation by foster et.al. (1981).

$$
\begin{aligned}
& \mathrm{K}=2.8^{*} 10^{-7} \mathrm{M}^{1.14}(12-\mathrm{a})+4.3 * 10^{-3}(\mathrm{~b}-2)+3.3^{*} 10^{-3}(\mathrm{c}-3) \\
& \mathrm{M}=(\% \text { silt }+\% \text { very fine sand }) *(100 \%-\% \text { clay }) \\
& \text { where } \\
& \quad \mathrm{M} \text { _particle size parameter } \\
& \text { a_percentage of organic matter } \\
& \text { b_soil structure code } \\
& \text { c_profile permeability class }
\end{aligned}
$$

Based on the soil class of study area, the soil data with K_factor added to GIS 10.3 to create Tin, Finally, the resulting shape file was changed to raster with a cell size of $30 \mathrm{~m}$ x $30 \mathrm{~m}$. The raster map was reclassified based on their type and the K_value corresponds to erodibility value were created. 


\subsubsection{LS-Factor (topography factor)}

A depression less (hydrologically corrected) Shuttle Radar Topography Mission (SRTM) digital elevation model (Jarvis et al., 2008) was used for the analysis of terrain attributes. Flow direction and flow accumulation were determined within ArcGIS 10.3 following the standard procedures. A slope map was generated from the DEM and slope length and the steepness factor (LS-factor) determined as given by Moore and Wilson (1992).

Slope Length (L_factor)

Using raster calculator in ArcGIS 10.3, value of L was determined using the following expression.

$\mathrm{L}=(\mathrm{POW}\{$ flow acc $\}+900,(\{\mathrm{~m}\}+1))-(\mathrm{POW}\{$ flow acc $\},\{\mathrm{m}\}+1)) /(\mathrm{POW}(30,\{\mathrm{~m}\}+2) \times$ pow $(22.13$, $\{\mathrm{m}\}))$

\section{Slope Steepness (S_factor)}

In ArcGIS 10.3, value of $\mathrm{S}$ was determined using the following expression:

$\mathrm{S}=\operatorname{con}(\tan (\{$ slope $\} \times 0.01745)<0.09,(10.8 \times \sin (\{$ slope $\} \times 0.01745)+0.03),(16.8 \times \sin (\{$ slope $\} \times 0.01745)$ $-0.5)$ )

The value of $\mathrm{m}$ varies from 0.2 to 0.5 depending on the slope as shown in Table 1 (Wischmeier and Smith, 1978) Table 1. M_value

\begin{tabular}{cc}
\hline m-value & Slope (\%) \\
\hline 0.5 & $>5$ \\
0.4 & $3-5$ \\
0.3 & $1-3$ \\
0.2 & $<1$
\end{tabular}

Source: - (Wischmeier and Smith, 1978)

Finally the value of L and S determined for each grid cell, the LS factor was then determined by multiplying the $\mathrm{L}$ and $\mathrm{S}$ value in Arc GIS 10.3 and a map of the LS factor was produced (section 4.3.3).

2.4.1.4. C-factor (land use land cover factor)

A land-use and land-cover of the study area was prepared from Land-sat 8 image (LDCM) (path 167 row 054) acquired on 12 February 2017 was trained and processed with zonal study area in ERDAS Imagine 10 software to extract the different landforms of the study area. The extracted data generates LULC map which was checked and completed through field observation and with the help of Google earth. Supervised image classifications technique was done, land use and land cover types where identified. The land use land cover classified changed to grid form and a corresponding C_value obtained from (Hurni, 1988, Eweg and van Lammeren, 1996, BCEOM, 1998, Wischmeier and Smith, 1978) was assigned in a GIS 10.3 environment.

Table 2. Land use and land cover (C_value) used in different studies.

$\begin{array}{lll}\text { Land-use and land-cover type } & \text { C factor value } & \text { References } \\ \text { Forest } & 0.02 & \text { Hurni (1988) } \\ \text { Grassland } & 0.01 & \text { Eweg and van Lammeren (1996) } \\ \text { Cultivated land (cereals/pulses) } & 0.17 & \text { Hurni (1988) } \\ \text { Bare land } & 0.60 & \text { BCEOM (1998) } \\ \text { Shrub } & 0.014 & \text { Wischmeier and Smith (1978) }\end{array}$

\subsubsection{P-factor (Conservation Practice factor)}

The P_value suggested by Bewket and Teferi (2009), Wischmeir and Smith (1978), Hurni (1985), Shi et al. (2002) and Shiferaw (2011): that considered only two types of land uses (agricultural and other land/nonagricultural) and land slopes adopted for Ethiopian condition were used. The agricultural land areas were classified into six slope categories and assigned $\mathrm{P}$ value; while non-agricultural land was assigned a $\mathrm{P}$ value of 1.00. A corresponding $P_{-}$value was assigned to agricultural and non-agricultural land by using the re-class method in Arc GIS 10.3.

Table 3. Conservation practice (P factors) based on slope and Land use (Shiferaw, 2011).

Land use type

Agricultural land

Other land All

\begin{tabular}{lc}
\multicolumn{1}{c}{ Slope (\%) } & P-factor \\
$0-5$ & 0.11 \\
$5-10$ & 0.12 \\
$10-20$ & 0.14 \\
$20-30$ & 0.22 \\
$30-50$ & 0.31 \\
$50-100$ & 0.43 \\
All & 1.00
\end{tabular}




\subsection{Soil Loss Analysis}

Annual soil loss rate was determined by using RUSLE factor values ( R, K, LS, C and P) in GIS environment "Spatial Analyst Tool, Map Algebra and Raster Calculator" in ArcGIS 10.3 software as shown in Equation 3.6. For the purpose of identifying priority areas for conservation planning, soil loss potential of the zone was then categorized in to different severity classes following FAO and UNEP guideline, (1984), (Section 4.6; Table 7).

Where

$$
\mathrm{A}=\mathrm{LS}^{*} \mathrm{R} * \mathrm{~K} * \mathrm{C} * \mathrm{P}
$$

A - is the annual soil loss (ton ha ${ }^{-1}$ year $\left.^{-1}\right)$;

$\mathrm{R}$ - is the rainfall erosive factor [MJ $\mathrm{mm} \mathrm{h}^{-1} \mathrm{ha}^{-1}$ year $^{-1}$;

$\mathrm{K}$ - is soil erodibility factor [ton ha h ha ${ }^{-1} \mathrm{MJ}^{-1} \mathrm{~mm}^{-1}$ ];

$\mathrm{LS}$ - is slope length factor (dimensionless);

$\mathrm{C}$ - is land cover and management factor (dimensionless); and

$\mathrm{P}$ - is conservation practice factor (dimensionless).

\subsection{Analysis of Soil Characteristics}

Five disturbed soil samples at $\left(0 \_15 \mathrm{~cm}\right)$ were taken from the four land use, land cover of the zonal woreda's which two samples were from bare land to determine soil textural class, organic matter content, structure and soil permeability to identify the characteristics of the soil as well as for K_factor identification. The soil character create the soil erodibility us below equation

$$
\mathrm{K}=\frac{(\mathrm{Kt} * \mathrm{Km})+(\mathrm{Ks}+\mathrm{Kp})}{100}
$$

where

$$
\begin{aligned}
& \text { K - Soil erodibility } \\
& \text { Kt - soil texture sub-factor } \\
& \text { Ko - soil organic matter sub-factor } \\
& \text { Ks - Soil structure sub-factor } \\
& \text { Kp - soil profile permeability sub-factor }
\end{aligned}
$$

This all factors were identified as below equation

$$
\mathrm{Kt}=\frac{2.1[(\mathrm{Pls}+\mathrm{Pvfs}) *(100-\mathrm{Pcl})]^{1.14}}{10,000}
$$

where

Pls - percentage of silt

Pvfs - percentage of very fine sand

$\mathrm{Pcl}$ - percentage of clay soil

$\mathrm{Ko}=(12-\mathrm{Om})$

where

Om - Percentage of inherent soil organic matter

$\mathrm{Ks}=3.25(\mathrm{Ss}-2)$

(3.10)

where

Ss - Soil structure class

$\mathrm{Kp}=2.5(\mathrm{Pr}-3)$

where

Pr - soil profile permeability rating

The soil samples taken were dried in air and big lumps were crushed with an aid of motor and pestle. Then it was passed into a $2 \mathrm{~mm}$ sieve and stored in polythene bags for final analysis. Hydrometer method was used for analyzing the soil texture. 50 grams of $2 \mathrm{~mm}$ sieved soil samples were weighed into a polythene bottle. Soil texture was determined at laboratory and the textural classes of the zonal area were represented on the soil textural triangle. Soil structure was determined by soil visual descriptors methods suggested by Shepherd (2000). To analyze permeability, undisturbed soil sample by core sampler from the field was taken. Subsequently, permeability was computed using laboratory method (constant head test method) proposed by Klute (1965). Organic carbon was determined by Walkely and Black 54 method (Bernard et al., 1993). The organic matter was 
calculated by multiplying the organic carbon by a factor of 1.724 . The value of soil characteristics were written under Appendix Table 3 and Appendix Table 4

\section{RESULTS AND DISCUSSION}

In this section, major findings of the study including characterization of zonal soil loss, land use land cover, soil loss management practice, and soil loss risk were presented.

\subsection{Physical Characteristics of the study area}

\subsubsection{Land use and land cover of study area}

The major land use and land cover class of west Hararghe zone are bare land, forest, cultivated, and settlement lands. Most part of the zone, more than $23 \%$ is bare land and the remaining land feature cover around $77 \%$ of the total land as shown in Table 4.

Table 4. Land use land cover feature class of study area

\begin{tabular}{lllccl}
\hline No & \multicolumn{1}{c}{ LULC feature } & Area coverage (ha) & $\begin{array}{c}\text { Area cover } \\
\text { in \% }\end{array}$ & C_factor & \multicolumn{1}{c}{ sources } \\
\hline 1 & Cultivated land & 388290.5753 & 23.5 & 0.25 & hurni, 1985 \\
2 & Dense bush shrub land & 24784.50481 & 1.5 & 0.01 & Asmamaw et al.,2012 \\
3 & Dense shrub land & 19827.60384 & 1.2 & 0.01 & Asmamaw et al.,2012 \\
4 & Bare land & 355244.5689 & 21.5 & 0.6 & BCEOM,1998 \\
5 & Forest & 168534.6327 & 10.2 & 0.02 & hurni, 1988 \\
6 & Irrigated agriculture & 62622.18214 & 3.79 & 0.25 & hurni,1985 \\
7 & Open bush shrub land & 37176.75721 & 2.25 & 0.01 & Asmamaw et al.,2012 \\
8 & Open grass land & 152011.6295 & 9.2 & 0.01 & Asmamaw et al.,2012 \\
9 & Open shrub grass land & 53699.76041 & 3.25 & 0.01 & Asmamaw et al.,2012 \\
10 & Open shrub land & 95833.41858 & 5.8 & 0.01 & Asmamaw et al.,2012 \\
11 & Open wood land & 19827.60384 & 1.2 & 0.015 & BCEOM,1998 \\
12 & Perennial marsh & 46264.40897 & 2.8 & 0.4 & BCEOM,1998 \\
13 & Riverine forest & 19827.60384 & 1.2 & 0.01 & hurni,1985 \\
14 & Seasonal marsh & 29741.40577 & 1.8 & 0.04 & BCEOM,1998 \\
15 & Settlements & 108390.901 & 6.56 & 0.05 & Asmamaw et al.,2012 \\
16 & Water body & 70222.76362 & 4.25 & 0.01 & bewket\&Teferi,2009 \\
\cline { 2 - 5 } & Total & $\mathbf{1 6 5 2 3 0 0 . 3 2}$ & $\mathbf{1 0 0}$ & & \\
\hline
\end{tabular}

The study area is mountains and steeper slope which is bare land. While forest lands were dispersed around the cultivated flat land area through the zone (Figure 4)

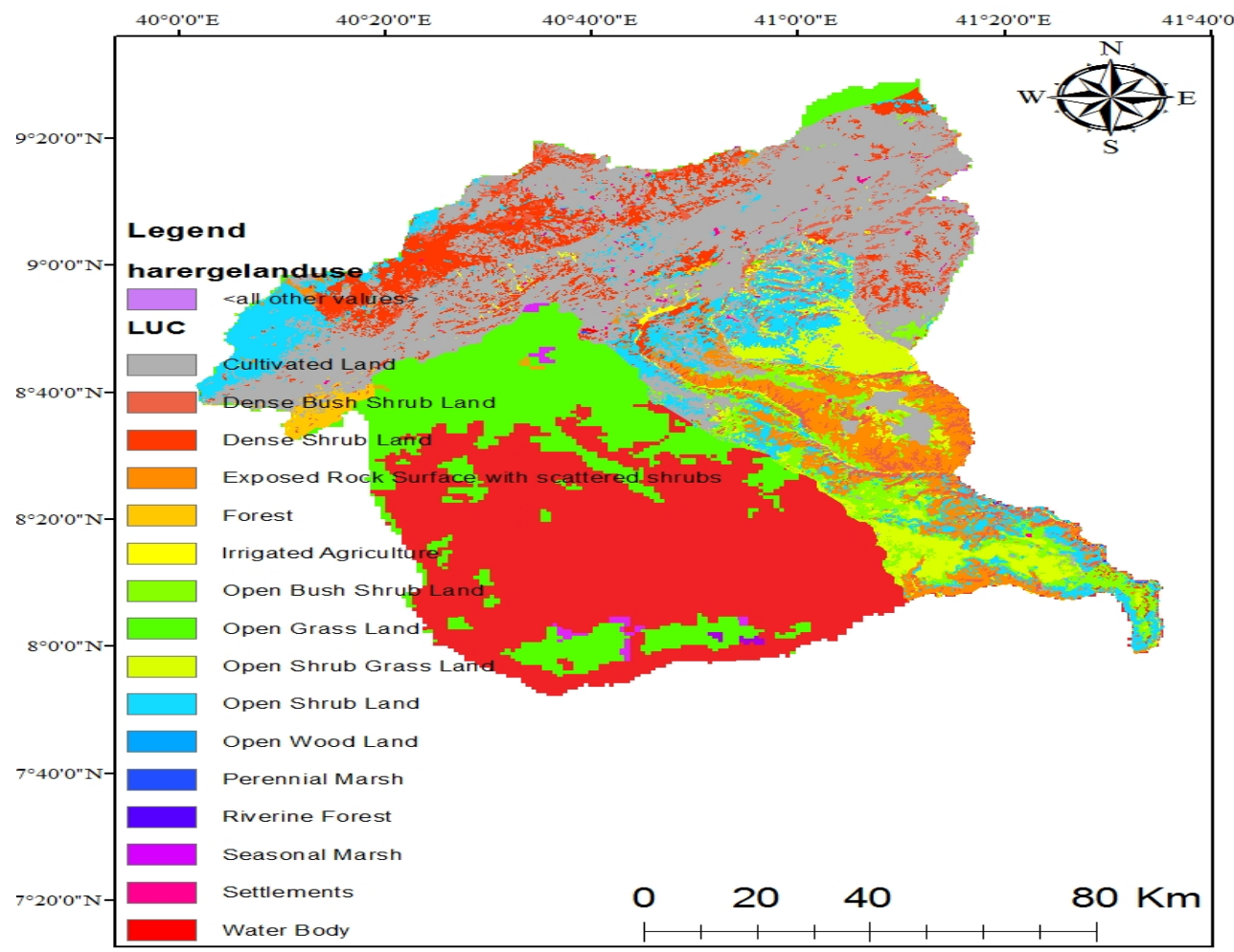

Figure 4. land use land cover of study area 


\subsubsection{Soil type of study area}

The zone was dominated by 12 soil class as the soil class of study area extracted and taken from Ethiopia soil class digital data. Which the study area were dominated with leptosols soil and vertisols type which covers more than $50 \%$ zonal area.

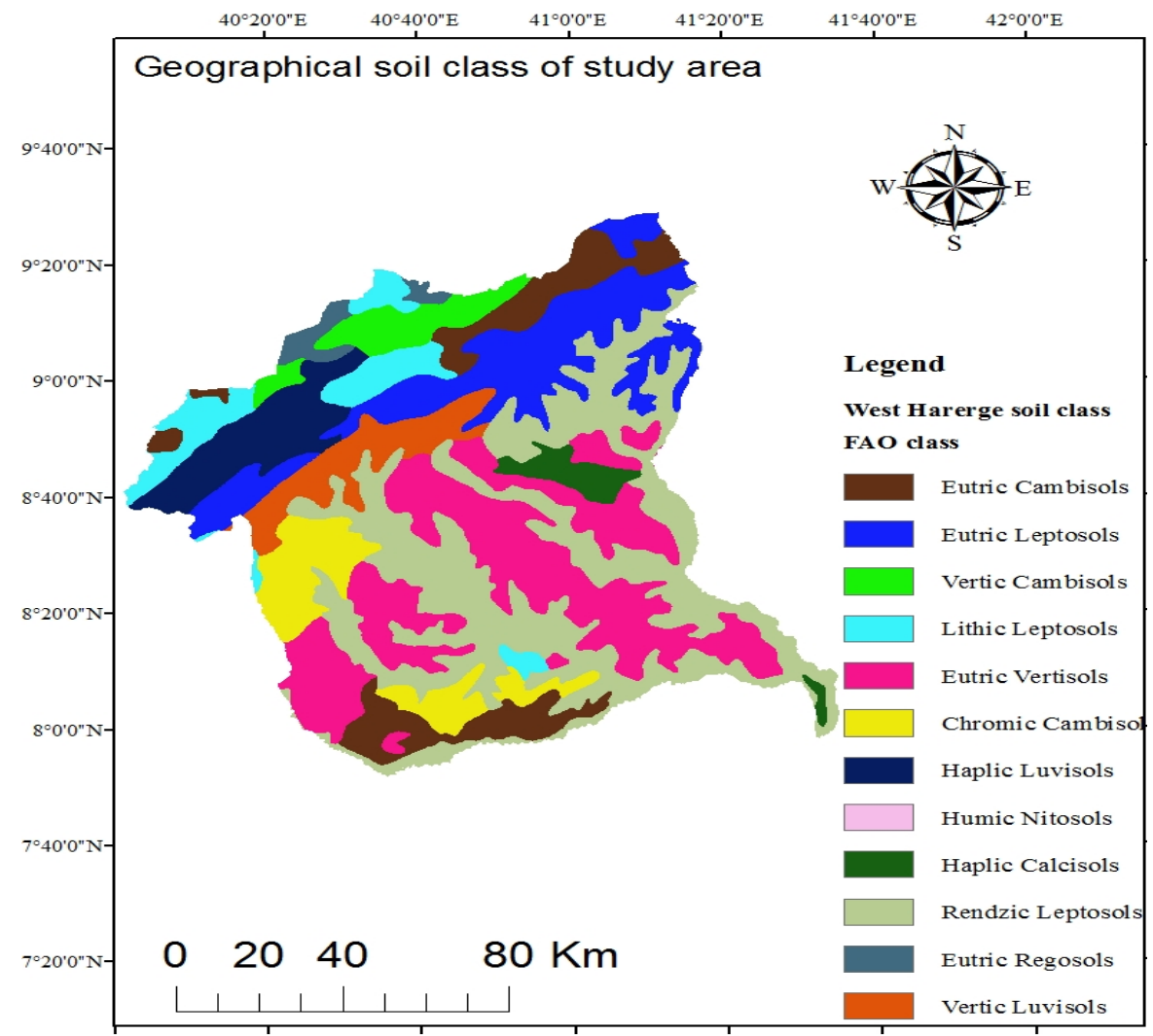

Figure 5. Soil type of West Harerge Zone

\subsection{Data Preparation}

\subsubsection{Estimation of missed rainfall data}

Inadequate and missed rainfall data for accurate measurement input was considered and estimated depending on the neighbor mean annual precipitation. The base station or west Harerghe zone metrological stations missed values were filled using XLSTAT tools (section 3.3.1.) and the results were written under Appendix Table.

\subsubsection{Consistency analysis and homogeneity test}

The double mass curve was plotted for annual cumulative total rainfall data of the base station (west Harerghe zone metrological stations) with the average annual cumulative data of neighborhood station. The graph of the double mass curve plot was found to be almost linear for base metrological station with coefficient of determination $\left(\mathrm{R}^{2}\right) 0.99$ which is 1.0 as shown in Appendix Figure. This implies that the rainfall data was consistent over the considered period of rainfall data.

According to the hypothesis test the result of homogeneity test for rainfall data shows that the collected data were homogeneous as homogeneity of the annual rainfall data from 1998 to 2017 shows. A sample test result for West Harerghe zonal stations show the restriction of homogeneity assured that the observation is from the same population Appendix Figure.

\subsubsection{Digital Elevation Model}

DEM of the study area created from contour map was digitized from the topographic maps of 1:60,000 scale with contour interval of $30 \mathrm{~m}$ as below Figure 6. 


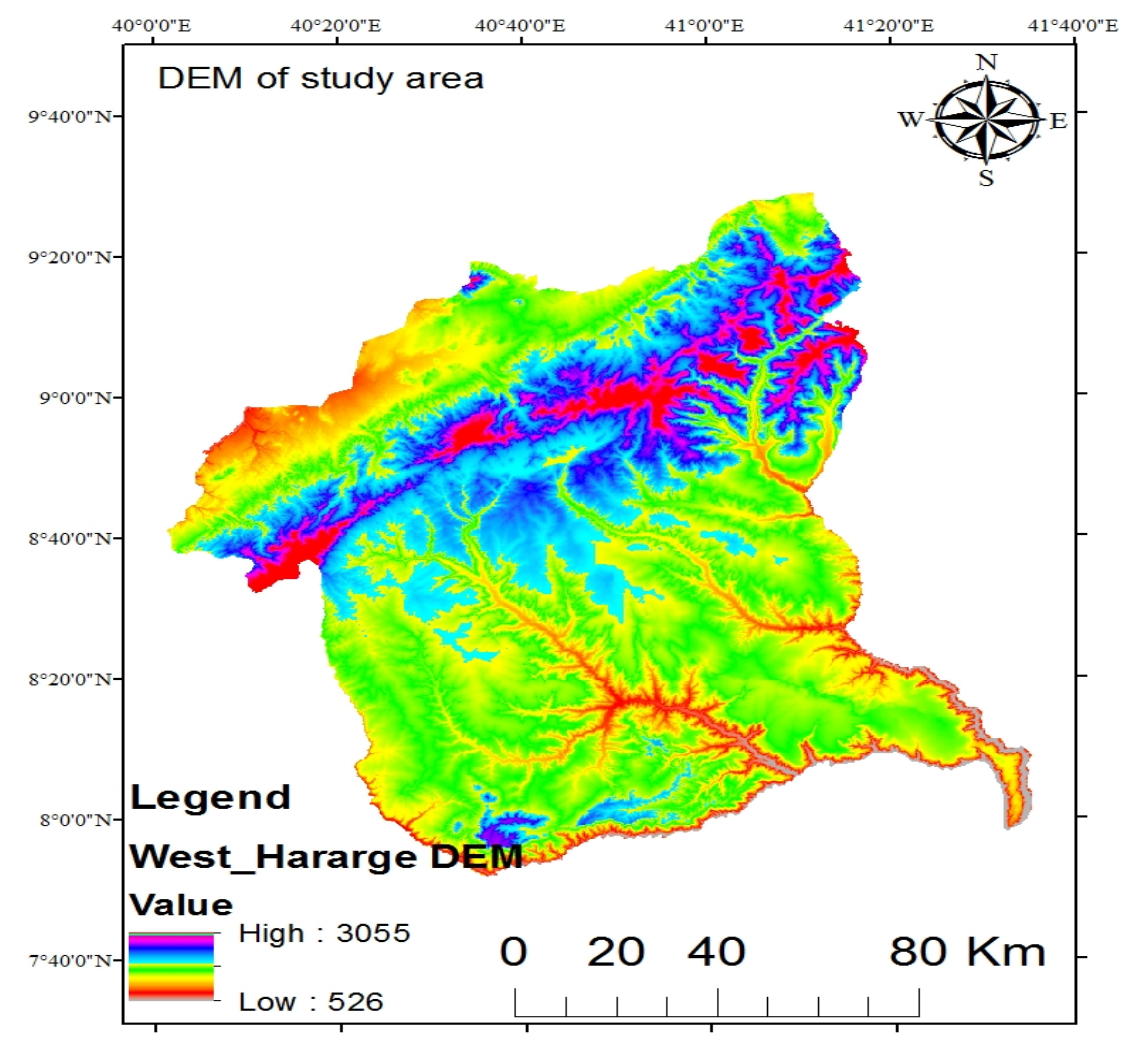

Figure 6. DEM of study watershed

\subsection{Soil Loss Factors of the Zone}

The model parameters (land use land coverage, soil loss management practices, rainfall erosive, soil erodibility and land topography) were identified.

\subsubsection{Rainfall erosive factor (R-Factor)}

Soil loss is closely related to rainfall partly through the detaching power of raindrops striking the soil surface and partly through the contribution of rain to runoff. The soil loss is closely related to rainfall partly through the detaching power of raindrop striking the soil surface and partly through the contribution of rain to runoff (Morgan, 2005). The representative mean annual rainfall of the study area is ranging $700-1230.36 \mathrm{~mm}$.

Table 5. Metrological Information of study area

\begin{tabular}{llrrrrr}
\hline No & station name & Latitude & Longitude & elevation & $\begin{array}{r}\text { mean annual rainfall } \\
(\mathbf{m m})\end{array}$ & erosivite \\
\hline 1 & Badessa & 8.90 & 40.77 & 1703 & 1230.00 & 683.14 \\
2 & Gelemso & 8.81 & 40.53 & 1739 & 1140.00 & 632.56 \\
3 & Kuni & 9.00 & 40.52 & 2455 & 1020.05 & 565.15 \\
4 & Meiso & 9.23 & 40.75 & 1332 & 680.65 & 374.41 \\
5 & Mechara & 8.59 & 40.31 & 1822 & 1175.00 & 652.23 \\
6 & Hirna & 9.21 & 41.22 & 1345 & 1010.00 & 559.50 \\
7 & Eerer & 9.33 & 41.22 & 1567 & 904.37 & 500.14 \\
8 & arbabordede & 9.00 & 40.38 & 1689 & 1078.00 & 597.72 \\
9 & tedecha belia & 8.12 & 41.01 & 1850 & 1100.00 & 610.08 \\
10 & Mekela & 9.13 & 41.10 & 170 & 820.00 & 452.72 \\
11 & Asebot & 9.17 & 40.75 & 1800 & 700.00 & 385.28 \\
12 & Chiro & 9.07 & 40.45 & 160 & 960.00 & 531.40 \\
13 & Chelanko & 9.40 & 41.57 & 1860 & 780.00 & 430.24 \\
\hline
\end{tabular}

Using the above data and Kriging technique in ArcGIS 10.3 rainfall erosive map of each neighboring metrological station and the study area rainfall erosive map were developed.

The result showed that R-factor value in the study area ranged between 375.59 to $681.571 \mathrm{MJ} \mathrm{mm} \mathrm{h}^{-1} \mathrm{ha}^{-1}$ year $^{-1}$ (Figure 7). 


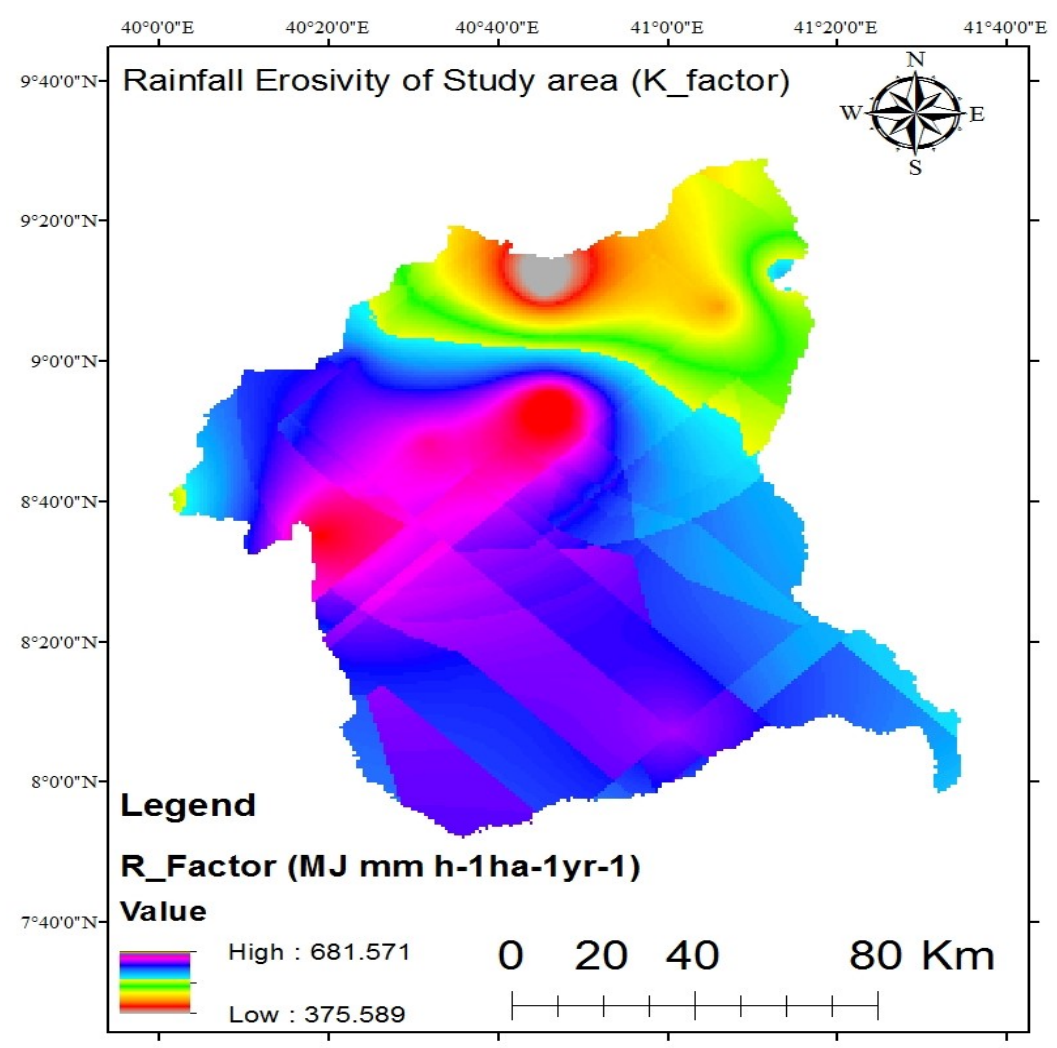

Figure 7. Rainfall erosive factor of study area/west Harerge Zone/

\subsubsection{Soil erodibility factor (K-Factor)}

The result indicated that soil erodibility value in the study area was 0.03 to 0.25 tons ha ha $-1 \mathrm{MJ}-1 \mathrm{~mm}-1$ (Table 7 and Figure 8).

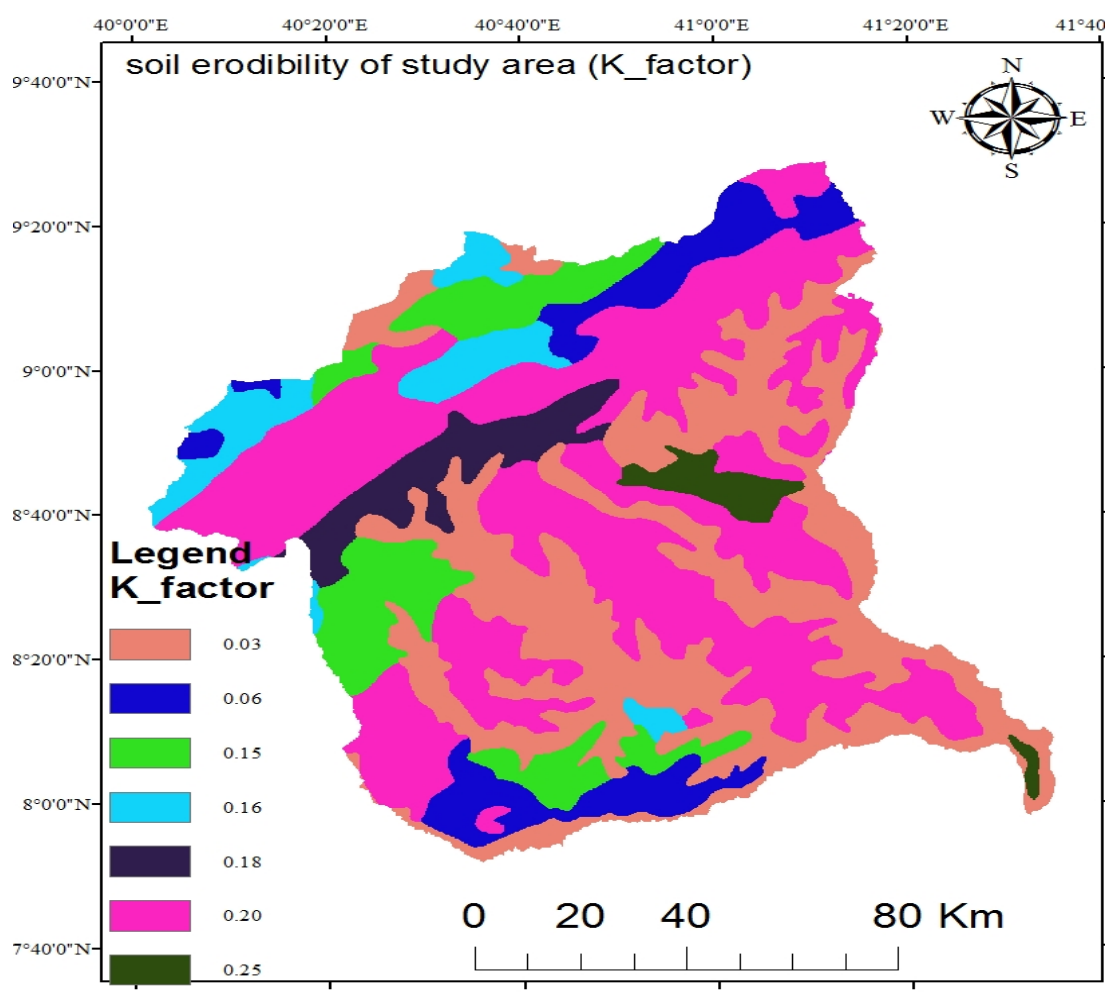

Figure 8. K_factor of west Harerghe zone 


\subsubsection{Topographic factor (LS_Factor)}

The steeper and longer the slope, the higher is the erosion. As slope length increases, total soil erosion and soil erosion per unit area increase due to the progressive accumulation of runoff in the down slope direction. The local slope gradient (S factor) influences flow velocity and the rate of erosion. Slope length (L factor) describes the distance between the origin and termination of inter-rill processes. The slope length factor and slope degree factors were typically combined together and the topographic factor map that was a function of both slope steepness and length of study area were developed (Figure 9).

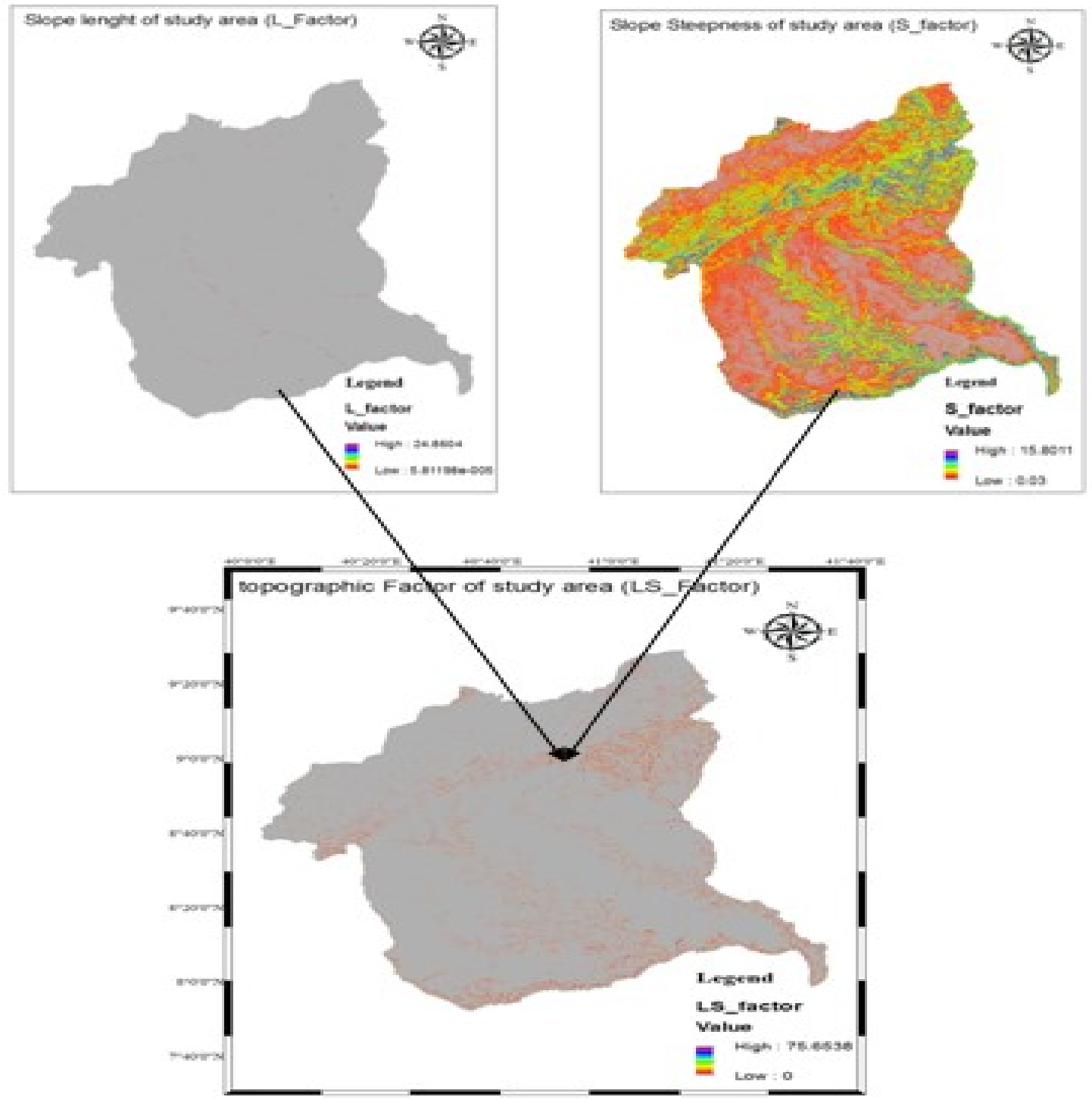

Figure 9. Topographic factor of study area (LS_factor)

\subsubsection{Land use land cover factor (C-factor)}

The attribute and spatial information on the present status of land use land cover is an important point to estimate soil loss, prioritize areas for soil conservation measures and minimizing further land degradation. The results of C_value indicated that the zonal area characterized as sixteen specific land use land cover classes (Table 4, section 4.1.1, and Figure 10). C- Factor values of the area were 0.01 to 0.6. 


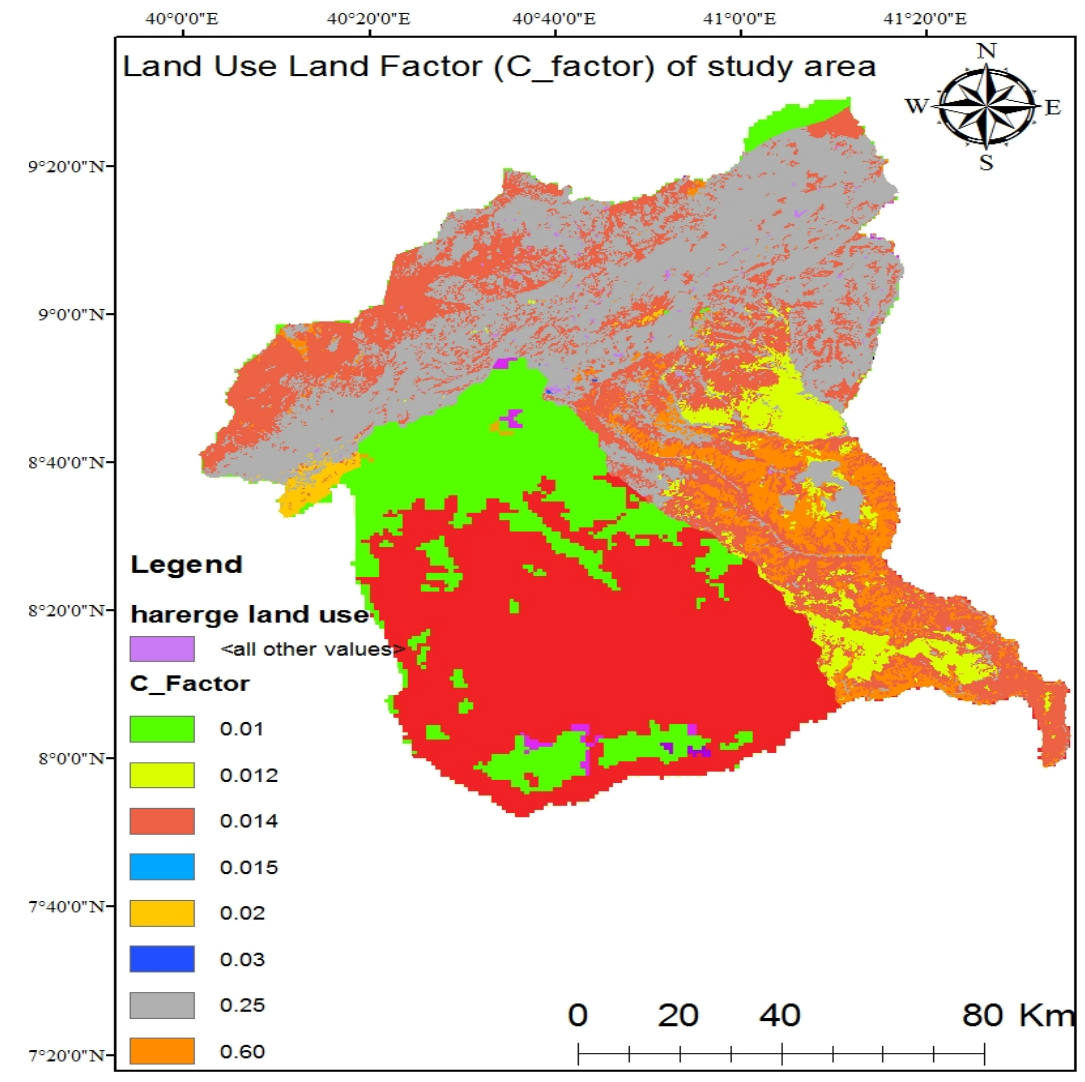

Figure 10. C_factor map of study watershed

\subsubsection{Conservation Practice factor (P-factor)}

The management practice factor is one of the factors that govern the soil erosion rate which reflects the effects of practices that will reduce the amount and rate of the water runoff and thus reduce the amount of erosion. It depends on the type of conservation measures implemented and requires mapping of conserved areas for it to be quantified. In the study area, attention given for management and conservation practices is rare, i.e. management practices are not that much. So it is advisable to calculate $\mathrm{P}_{-}$factor of the zonal area as suggested by Shiferaw (2011).

Slope map, field information and land use/ land cover map were used to choose suitable $\mathrm{P}_{-}$factor of watershed, with this general information and procedure the $\mathrm{P}_{-}$factor of watershed ranges from 0.1 to 0.9 (Figure 11). 


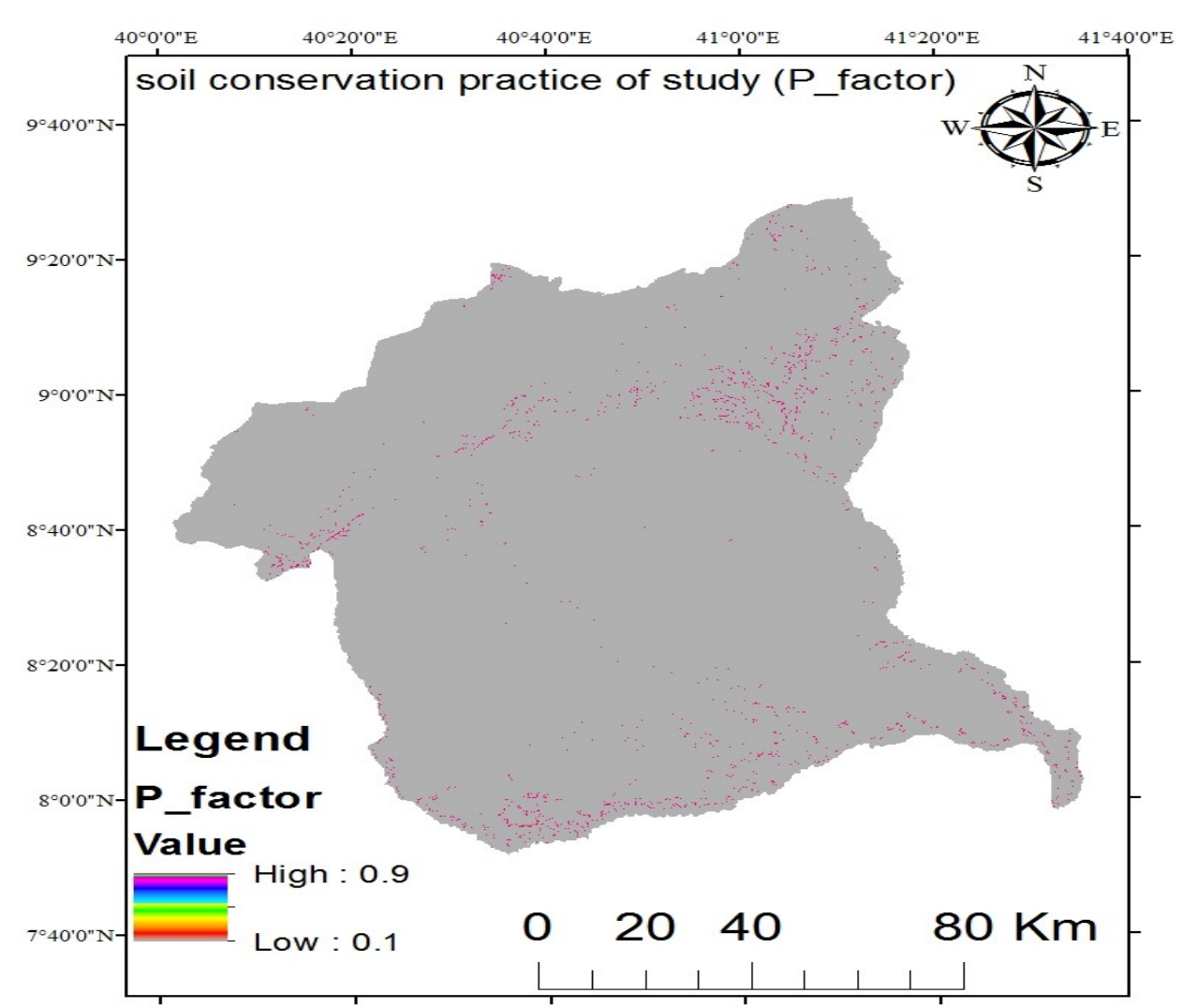

Figure 11. P_factor of study area

\subsection{Estimated Soil Loss of West Harerghe Zone}

This study was carried out to spatially predict the soil loss rate of West Harghe zone, Eastern Ethiopia with a Geographic Information System (GIS) and Remote Sensing (RS). The Revised Universal Soil Loss Equation (RUSLE) has been used widely all over the world including Ethiopia (Kaltenrieder, 2007) because of its simplicity and limited data requirement. The advent of geographical information system (GIS) technology has allowed the equation to be used in a spatially distributed manner because each cell in a raster image comes to represent a field-level unit. Even though the equation was originally meant for predicting soil erosion at the field scale, its use for large areas in a GIS platform has produced satisfactory results.

Revised Universal Soil Loss Equation (RUSLE) adapted to Ethiopian conditions was used to estimate potential soil losses by utilizing information on rainfall erosive (R) using interpolation of rainfall data, soil erodibility (K) using soil map, vegetation cover $(\mathrm{C})$ using satellite images, topography (LS) using Digital Elevation Model and conservation practices $(\mathrm{P})$ using satellite images.

Based on the analysis, the annual average soil loss of the zone was estimated as $28.62 \mathrm{ton} / \mathrm{ha} / \mathrm{yr}$ which is within the range of soil loss estimate for Ethiopian highlands by the soil conservation research project (SCRP) which ranges from 0 to 300 ton/ha/yr (Nyssen et al., 2004) and Bobe (2004) as estimated in East and west Hararghe zone districts, in the range of 1.74-135 t/ha/yr. The total annual soil loss potential from 1,652,300.32ha zone was $47,288,835.17$ tons $\mathrm{yr}^{-1}$ at $2017 / 18$. About $27.70 \%$ (457,687.19 ha) of zone was classified under high to very high soil loss class while the remaining $72.30 \%(1,194,613.1314 \mathrm{ha})$ of the zone categorized under slow to moderate soil loss class (Mati et al., 2000) (Table 7).

The normal SLT (soil loss tolerance) value for Ethiopia ranges from 2 to 16 tons $\mathrm{ha}^{-1} \mathrm{yr}^{-1}$ (Hurni et al., 2008). This denotes the maximum allowable soil loss that will sustain an economic (Wischmeier and Smith, 1978; FAO and UNEP, 1984 \& Gebreyesus and Kirubel, 2009) and a high level of productivity. In this study, the area with a soil loss potential higher than the SLT was $1,495,331.79$ ha (Table 7) that accounts $90.5 \%$ of total area coverage. 
Table 6. Soil loss class and Risk level

\begin{tabular}{|c|c|c|c|c|c|c|}
\hline No & $\begin{array}{c}\text { soil loss } \\
\text { class }\end{array}$ & $\begin{array}{c}\text { soil loss rating } \\
\text { (ton/ha/yr) }\end{array}$ & Description & area coverage (ha) & $\begin{array}{l}\% \text { of area } \\
\text { coverage }\end{array}$ & Priority \\
\hline 1 & I & $0.0-5.0$ & None & 115661.0224 & 7 & 6 \\
\hline 2 & II & $6.0-15.0$ & Slight & 41307.50801 & 2.5 & 5 \\
\hline 3 & III & $16.0-30.0$ & Moderate & 707184.5371 & 42.8 & 4 \\
\hline 4 & IV & $31.0-50.0$ & Moderate & 330460.0641 & 20 & 3 \\
\hline 5 & $\mathrm{~V}$ & $51.0-200.0$ & High & 305675.5593 & 18.5 & 2 \\
\hline \multirow[t]{5}{*}{6} & VI & $>200$ & Very High & 152011.6295 & 9.2 & 1 \\
\hline & & total & & 1652300.32 & 100 & \\
\hline & & & & Minimum & 1 ton/ha/yr & \\
\hline & & & & Maximum & $401.10 \mathrm{ton} / \mathrm{ha} / \mathrm{yr}$ & \\
\hline & & & & Annual loss Average & $28.62 \mathrm{ton} / \mathrm{ha} / \mathrm{yr}$ & \\
\hline
\end{tabular}

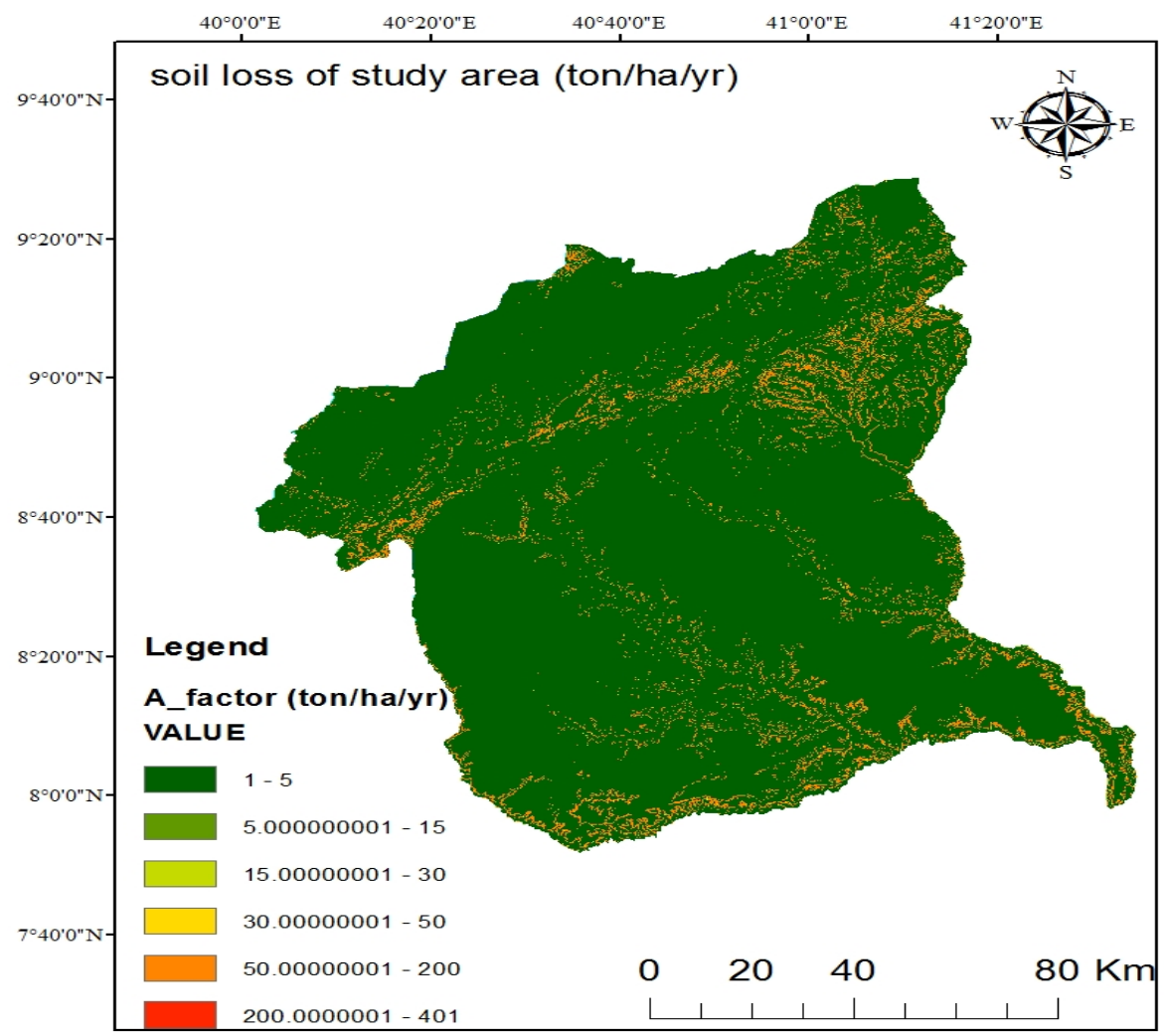

Figure 12. West Harerge Soil loss map

\section{SUMMARY, CONCLUSIONS AND RECOMMENDATIONS}

\subsection{Summary and Conclusions}

Land degradation and particularly soil erosion by water not only reduce the productivity of the land but also aggravated the effects of drought, such as famine and migration. Obvious signs of degradation in the highlands of Ethiopia are wide gullies swallowing fertile lands and rock-out crops making farming a risky business. But also less visible sheet erosion processes result in a tremendous loss of fertile topsoil, particularly on cropland.

The problem of accelerating land degradation is especially serious in the intensively cultivated highland parts of the country (Bewket, 2007). Owing to the inherently good soils and relatively abundant rainfall the highlands ( $>1500$ meters above sea level) cover about 46 percent of the land mass, account for 95 percent of the regularly cultivated lands, and support about 88 percent of the human and 75 percent of the livestock population; and these aggravate degradation problems (Haile, 2006).

The study area, west Hararghe Zone is dominated by high soil erosion. In this area much of the land is degraded and become bare land due to luck of soil conservation on the area. The general objective of this study was to estimate the rate of soil erosion and soil loss potential of western Hararghe zone, eastern Ethiopia. 
To understand the effect of soil loss and to take controlling measurement, the study has done on west Hararghe zone. This approach, supported with RUSLE together with GIS 10.3 provides great advantage to estimate soil loss rate over areas. The steps followed include data base establishment from primary and secondary data source using ArcGIS 10.3 software. In addition, data were collected through field sampling, field measurement, surveying equipment and field observation. Based on RUSLE model analysis the total amount of soil loss from west Hararghe was estimated to be zone was 47,288,835.17 tons year-1 from 1,652,300.32 ha area with annual average soil loss of $28.62 \mathrm{ton} / \mathrm{ha} / \mathrm{yr}$. The annual soil loss of the study area lay in the documented range of soil loss of Ethiopian highland (Hurni et al., 2008). The soil loss of each parcel in the watersheds was found in the range of 1 to $401 \mathrm{tha}^{-1} \mathrm{yr}^{-1}$.

\subsection{Recommendations}

Based on the findings of this study, the following recommendations were made in order to address the rainfall soil loss and land degradation.

The areas with a high and increasing soil erosion risk were identified and mapped which conservation priorities identified in the present study can serve as a spatial decision support tool and as input for decision makers and conservation planners for future intervention measures in highly affected areas, and the priority should given for this areas to apply SWC structures.

Proper soil conservation structure should be projected in this area, to control soil loss and to mitigate the society economically and socially.

Further study should be conducted on the area to identify the impact of sediment deposition on command area and productivity of agricultural land.

The area with great soil loss should get attention based on their priority to develop soil and water conservation structures.

\section{ACKNOWLEDGEMENTS}

Above all we would thank the Almighty and Merciful God for giving us strength, health, peace and encouragement in all our life and for enabling us to complete this research work successfully.. We would like to express our sincere appreciations gratitude and profound thanks to west Harerghe community for their welcome approach and interesting cooperation during data collection. We thank Oda Bultum University Research and Community Engagement Director Directorate for sponsoring this research fully.

\section{Reference}

Adediji, A.; Tukur, A.M.; Adepoju, K.A. Assessment of Revised Universal Soil Loss Equation (RUSLE) in Katsina Area, Katsina State of Nigeria using Remote Sensing (RS) and Geographic Information System (GIS). Iran. J. Energy Environ. 2010, 1, 255-264.

Araya, A., Stroosnijder, L.; Habtu, S.; Keesstra, S. D.; Berhe, M.; Hadgu, K. M. Risk assessment by sowing date for barley (Hordeum vulgare) in northern Ethiopia. Agric. for. Meteorol. 2012, 154, 30-37.

Assefa Admassie, Berhanu Adenew and Abebe Tadege (2008). Perceptions of stakeholders' on climate change and adaptation strategies in Ethiopia, EEA Research Report.

Atnafe, A. D., Ahmed, H. M., \& Adane, D. M. (2015). Determinants of adopting techniques of soil and water conservation in Goromti Watershed, Western Ethiopia, 6(6), 168-177. https://doi.org/10.5897/JSSEM15.

Ayalew, G. Geographic information system based soil loss estimation in Zingin Watershed for soil conservation planning, highlands of Ethiopia. Int. J. Sci. Technol. Soc. 2015, 3, 28-35, doi:10.11648/j.ijsts.20150301.14.

Barakat, M.; Mahfoud, I.; Kwyes, A.A. Study of soil erosion risk in the Basin of Northern Al-Kabeer River at Lattakia-Syria using remote sensing and GIS techniques. Mesopot. J. Mar. Sci. 2014, 29, 29-44.

Batjes, N. H. (2001). Options for increasing carbon, sequestration in West African Soils: An Explanatory Study with Special Focus on Senegal Land Degradation and Development 12:Pp 131-142.

Berry, L., Olson, J., \& Campbell, D. (2003). Assessing the Extent Cost and Impact of Land Degradation at the National Level: Overview: Findings and Lessons Learned, (March). http://doi.org/citeulike-articleid:13073971

Betelhem abebe, 2018. Perception of smallholder farmers' on climate change and variability in dire dawa administration. Department of Geography and Environmental Studies, Mizan-Tepi University, Ethiopia. International journal of advanced research)

Bezuayehu Tefera, Gezahegn Ayele, Yigezu Atnafe, Jabbar M.A. and Paulos Dubale. 2002. Nature and causes of land degradation in the Oromiya Region: A review. Socio-economics and Policy Research Working Paper 36. ILRI (International Livestock Research Institute), Nairobi, Kenya. 82 pp.

Chang, T.J.; Zhou, H.; Guan, Y. Applications of Erosion Hotspots for Watershed Investigation in the Appalachian Hills of the United States. J. Irrig. Drain Eng. 2016, 142, doi:10.1061/(ASCE)IR.19434774.0000974. 
Claessens, L.; Breugel, P.V.; Notenbaert, A.; Herrero, M.; De Steeg, J.V. Mapping potential soil erosion in East Africa using the Universal Soil Loss Equation and secondary data California, USA. In Sediment Dynamics in Changing Environments, Proceedings of a Symposium Held in Christchurch, New Zealand, 1-5 December 2008; IAHS Publication: Wallingford, UK, 2008; p. 588.

Community-Based Participatory Watershed Management (CBPWM). Integrated Watershed Management in Rainfed Agriculture; CRC Press: Leiden, The Netherlands, 2005.

Demirci, A. and Karaburun, A. (2012). Estimation of Soil Erosion Using RUSLE in A GIS Framework: A Case Study in the Buyukcekmece Lake Watershed, Northwest Turkey. Environmental Earth Sciences, 66(3): 903-913.

Devi, R., Tesfahune, E., Legesse, W., Deboch, B., and Beyene, A. (2008). Assessment of siltation and Nutrient Enrichment of Gilgel Gibe Dam, Southwest Ethiopia. Bioresource Technology, 9(5): 975-979.

Diagana, B. (2003). Land Degradation in Sub-Saharan Africa: What Explains the Wide-spread Adoption of the Unsustainable Farming Practices? Department of Agricultural Economics and Economics. Montana State University, Bozeman, M. T. USA.

Erenstein. Sustainable Poverty Reduction in Less Favored Area; Cromwell Press: Trowbridge, UK, 1999.

FAO (1998a). Ethiopia: Soil Fertility Initiative. FAO, Investment Centre Division. Concept Paper, Rome.

Food and Agriculture Organization (FAO). Ethiopian Highland Reclamation Study; Final Report; FAO: Rome, Italy, 1986; pp. 37-46.

Food and Agriculture Organization (FAO). Ethiopian Highland Reclamation Study (EHRS); Final Report; FAO: Rome, Italy, 1984.

Ganasri, B.P.; Ramesh, H. Assessment of soil erosion by RUSLE model using remote sensing and GIS, a case study of Nethravathi Basin. Geosci. Front. 2016, 7, 953-961, doi:10.1016/j.gsf.2015.10.007.

Gebreyesus, B.; Lulseged, T.; Paul, L.G. Soil Erosion Prediction Using Morgan-Morgan-Finney Model in a GIS Environment in Northern Ethiopia Catchment. Appl. Environ. Soil Sci. 2014, 2014, 468751.

Gobin, A., Govers, G., Jones, R., Kirkby, M., Kosmas, C. (2002). Assessment and Reporting on Soil Erosion Background and Workshop Report. Technical Report. European Environment Agency.

Haile, M. (2006). Sustainable Land Management - A New Approach to Soil and Water Conservation in Ethiopia Sustainable Land Management - A New Approach to Soil and Water Conservation in Ethiopia.

Hurni, H. Degradation and Conservation of the Resources in the Ethiopian highlands. Mt. Res. Dev. 1988, 8, $123-130$.

IDS (Institute of Development Studies), 2008. Economic Impacts of Climate Change in Ethiopia.

International Food Policy Research Institute. IFPRI (1999). Soil Degradation - A Threat to Developing Country Food Security by 2020? 2020 Vision for Food, Agriculture, and the Environment. Discussion Paper 27 p.70

K.G. Renard, G.R. Foster, G.A.Weesies, D.K. McCool, and D.C. Yoder. Predicting soil erosion by water: A guide to conservation planning with the Revised Universal Soil Loss Equation (RUSLE). Agriculture Research Service, United States Department of Agriculture, Hyattsville, Maryland, 1997.

Ketema, M., \& Bauer, S. (2012). Agris on-line Papers in Economics and Informatics Factors Affecting Intercropping and Conservation Tillage Practices in Eeastern Ethiopia Key words pping and conservation tillage, $I V(1), 21-29$.

Kirchhoff, M.; Rodrigo-Comino, J.; Seeger, M.; Ries, J. B. Soil erosion in sloping vineyards under conventional and organic land use managements (Saar-Mosel valley, Germany). Cuadernos de Investigación Geográfica 2017, 43, 119-140; doi: http://doi.org/10.18172/cig.3161.

Lal, R. Soil degradation by erosion. Land Degrad. Dev. 2001, 12, 519-539.

Lencha, B. K., \& Moges, A. (2015). Identification of Soil Erosion Hotspots in Jimma Zone (Ethiopia) Using GIS Based Approach. Ethiopian Journal of Environmental Studies \& Management, 8(Suppl 2), 926-938. https://doi.org/10.1017/CBO9781107415324.004

Li, X.S.; Wu, B.F.; Wang, H.; Zhang, J. Regional soil erosion risk assessment in Hai Basin. J. Remote Sens. $2011,15,372-387$.

Mellerowicz, K.; Ress, H.; Chow, T.; Ghanem, I. Soil conservation planning at the watershed level using the Universal Soil Loss Equation with GIS and microcomputer technologies: A case study. J. Soil Water Conserv. 1994, 49, 194-200.

Mideksa K. (2010). Economic and distributional impacts of climate change: the case of Ethiopia. Global environ. Change, doi:10.1016/j.gloenvcha.2009.11.007.

Morgan, R.P.C.; Quinton, J.N.; Smith, R.E.; Govers, G.; Poesen, J.W.A.; Auerswald, K.; Chisci, G.; Torri, D.; Styczen, M.E. The European Soil Erosion Model (EUROSEM): A dynamic approach for predicting sediment transport from fields and small catchments. Earth Surf. Process. Landf. 1998, 23, 527-544, doi:10.1002/(SICI) 1096-9837(199806)23:6<527::AID-ESP868>3.0.CO;2-5.

Nevena Dragicevic, Barbara Karleusa, and Nevenka Ozanic. A review of the gavrilovic method (erosion 
potential method) application. Gradevinar, 68:715\{725, 2016.

Niu D.; Wang H and Lai L. (2003) Soil Erosion and Conservation; http://159.226.205.16/curriculum/3w/ 01/cause/index.html; visited on November 12, 2009.

Panagos, P.; Borrelli, P.; Meusburger, K. A New European Slope Length and Steepness Factor (LS-Factor) for Modeling Soil Erosion by Water. Geosciences 2015, 5, 117-126.

Renard, K.G.; Foster, G.R.; Weesies, G.A.; McCool, D.K.; Yoder, D.C. Predicting Soil Erosion by Water: A Guide to Conservation Planning with the Revised Universal Soil Loss Equation (RUSLE); Agriculture Handbook; USDA: Washington, DC, USA, 1997; Volume 703, pp. 1-251.

Richarde Marques da Silva, Celso A.G. Santos, and Alexandro Medeiros Silva. Predicting soil erosion and sediment yield in the tapacura catchment, brazil. Journal of Urban and Evironmental \& Engineering, $8: 75\{82,2014$.

Sonneveld, B. (2002). Land under Pressure: Impact of Water Erosion on Food Production in Ethiopia, Shaker publishing the Netherlands.

Taffa T (2002). Soil and Water Conservation for Sustainable Agriculture. Mega publishing enterprise, Addis Ababa.

Tamene, L.; Vlek, P.L.G. GIS-based landscape characterization to assess soil erosion and its delivery potential in the highlands of northern Ethiopia. In Proceedings of the 1st International Conference on Remote Sensing and Geoinformation Processing in the Assessment and Monitoring of Land Degradation and Desertification, Trier, Germany, 7-9 September 2005; pp. 332-339.

Tefera, B., Ayele, G., Atnafe, Y., Jabbar, M. a, \& Dubale, P. (2002). Nature and causes of land degradation in the Oromya Region: a review, (August 2015).

Teklu E, Gezahegn A (2003). Indigenous Knowledge and Practices for Soil and Water Management in East Wollega, Ethiopia, Conference on International Agricultural Research for Development. Available at http://www.tropentag.de/2003/abstracts/full/364.pdf. Available http://www.tropentag.de/2003/abstracts/links/Erkossa_DiG4j4Tt.pdf

The Federal Democratic Republic of Ethiopia (FDRE). Ethiopia's Climate-Resilient Green Economy, Green Economy Strategy; Environmental Protection Authority: Addis Ababa, Ethiopia, 2011.

The Federal Democratic Republic of Ethiopia (FDRE). Growth and Transformation Plan (GTP); Ministry of Finance and Economic Development (MoFED): Addis Ababa, Ethiopia, 2010.

The Federal Democratic Republic of Ethiopia (FDRE). Rural Development Policy and Strategies; Ministry of Finance and Economic Development Economic Policy and Planning Department: Addis Ababa, Ethiopia, 2003.

Tripathi, M.P.; Panda, R.K.; Raghuwanshi, N.S. Identification and prioritization of critical sub-watersheds for soil conservation management using the SWAT model. Biosyst. Eng. 2003, 85, 365-379.

United Nations (2008). Situation report: Drought/Food crisis in Ethiopia 27th June 2008.

USAID (2004). Breaking the cycle of food crises: famine prevention in Ethiopia.

Utuk, I. O. (2015). Published Ph, D. dissertation Land Degradation: A Threat to Food Security: A Global Assessment, 5(8), 13-22.

W.S. Merritt, R.A. Letchera, and A.J. Jakeman. A review of erosion and sediment transport models. Environmental Modelling \& Software, 18:761\{799, 2003.

Walter H. Wischmeier and Dwight D. Smith. Predicting rainfall erosion losses - A guide to conservation planning. Science and Education Administration, United States Department of Agriculture, Hyattsville, Maryland, 1978.

Williams,J.R.Sediment routing for Agricultural Watersheds. Water Resour.Bull.1975,11,965-974.

World Bank (2000).The World Bank Group Countries: Ethiopia. Washington, D.C.

World Bank (2003). Africa rainfall and temperature evaluation system. World Bank, Washington, DC. 